\title{
Correlation of Polynuclear Aromatic Hydrocarbons with Environmental Components in Sediment from Hirakata Bay, Japan
}

\author{
Hajime Matsushima* \\ Faculty of Science, Tokyo Metropolitan University, Setagaya-ku, Tokyo 157
}

Received December 21, 1978

\begin{abstract}
Polynuclear aromatic hydrocarbons (PAH) including fiuoranthene, pyrene, 1,2-benzanthracene, chrysene, 3,4-benzpyrene (1,2-benzpyrene) and 1,12-benzperylene, were identified in sediments from Hirakata Bay. Their concentrations were proved to be in the range from several hundred $\mu \mathrm{g} / \mathrm{kg}$ to several $\mathrm{mg} / \mathrm{kg}$ of dry samples.

Significant positive correlations were statistically found between total amount of PAH and $\mathrm{Pb}, \mathrm{Hg}, \mathrm{Cd}, \mathrm{Cu}, \mathrm{Zn}$ and ignition loss in bay sediment. In addition, significant positive correlations were statistically found between ignition loss and the content of clay as well as the sum of (clay + silt) contents for both river and bay sediments. Based on the fact, it is presumed that organic substances in sediments are present in an adsorbed form to clay and silt.
\end{abstract}

Polynuclear aromatic hydrocarbons (PAH), mainly formed by incomplete combustion or pyrolysis of organic substances such as petroleum, coal and wood, are distributed not only in urban and industrial areas but also widely in the natural environment. Since municipal and industrial effluents, atmospheric precipitation and fall-out are supply sources of PAH to the aquatic environment, a marked pollution has been noted in the river water running through the urban and industrial districts, and sea shore water. Since PAH are fat-soluble, it is presumed that PAH are transported with suspended solids or seston in water, and finally, a large proportion of the $\mathrm{PAH}$ is removed from water by sedimentation, while a part is concentrated in fish and shellfish via aquatic food chains. Information on the correlation of $\mathrm{PAH}$ with environmental components in sediment is important to explain the behavior of PAH in the aquatic environment.

Giger et al. ${ }^{1 /}$ have determined the concentrations of PAH in sediments from Buzzards Bay, USA. Greffard et al. ${ }^{2>}$ have found the presence of 1 to $1710 \mu \mathrm{g} / \mathrm{kg}$ of dry samples of 3, 4-benzpyrene in sediments from Toulon Bay, France. Mallet et $a l^{31}$ have found 5

* Present Address: Hamamatsu University School of Medicine, Hamamatsu-shi, Shizuoka 431-31. $\mu \mathrm{g} / \mathrm{kg}$ of dry samples of 3,4-benzpyrene in sediments at the west coast of Greenland, where ships navigate scarcely and is practically an uninhabited area. They presumed that not only surface water, ship waste, atmospheric precipitation or fall-out, but also biosynthesis by aquatic plants might be the sources of PAH. In our country, Tomita et $a l^{4}$ ) have reported the presence of 2.9 to $255.2 \mu \mathrm{g} / \mathrm{kg}$ of dry samples of 3,4-benzpyrene in sediments from the Lake Hamana. Tatsukawa et $a .^{5}$ ' have determined the concentrations of anthracene and phenanthrene in sediments from Seto Inland Sea, and showed the concentrations to be $20 \sim 430$ and $20 \sim 81 \mu \mathrm{g} /$ $\mathrm{kg}$ of dry samples, respectively. Kawakami et $a l^{\left({ }^{6}\right)}$ have suggested that the main source of 3, 4-benzpyrene in sediments from Osaka Bay and Keihin Canal might be coke industrial effluent, based on the distribution of 3,4benzpyrene.

For the purpose of obtaining the data which may serve to explain the behavior of PAH in Hirakata Bay, Yokohama, the authors have determined the concentrations of PAH, heavy metals, ignition loss, and particle-size composition in sediments of Hirakata Bay. In this paper, the distribution of PAH and the statistical correlation of PAH with environmental components in sediments are reported. 


\section{SAMPLING AND ANALYSES}

Sediments in Hirakata Bay, Tokyo Bay and rivers which flow into Hirakata Bay, were collected four times in a period from August, 1973 to May, 1974, at sampling stations shown in Fig. 1. Hirakata Bay is situated in

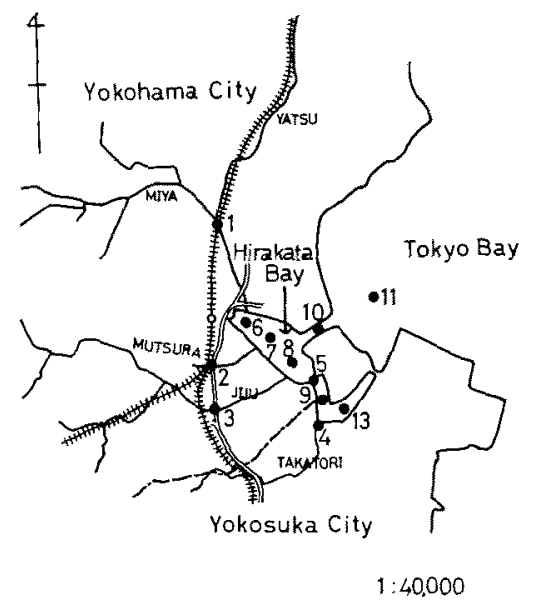

FIG. 1. Sampling Stations in Hirakata Bay, Tokyo Bay and Rivers Which Flow into Hirakata Bay. Sampling station.

Kanazawa-ku, Yokohama, and four rivers, namely the Miya, the Mutsura, the Jiju and the Takatori Rivers, enter into Hirakata Bay. Because Kanazawaku has a population of about 137,000 (census taken in October, 1976) and no sewer system including a final sewage disposal is set up, almost all domestic and indus- trial effluents directly flow through the river into Hirakata Bay. Since factories around Hirakata Bay are mainly manufacturing automobile parts, it is characteristic that the effluents from metal surface treating and plating factories discharge into the rivers. The four river waters and sediments are contaminated by the organic substances in the effluents, especially in domestic effluent, a marked pollution of organic substances has been detected in water and sediment of Hirakata Bay.

PAH in sediments were identified and determined according to the procedure already reported (Matsushima et $\left.a l^{7}\right)$, which consists of solvent extraction, clean up and fractionation by column chromatography, identification and determination by mass fragmentography. Heavy metals in sediments were determined using atomic absorption spectrophotometry by Nakagawa et $a l^{8)}$ and ignition loss was measured gravimetrically by use of a reducing flame. The content of gravel was measured by use of a $2 \mathrm{~mm}$ sieve. Contents of coarse sand + fine sand, silt and clay were measured gravimetrically by a dispersion procedure.

\section{RESULTS AND DISCUSSION}

Results of analyses of PAH, heavy metals and ignition loss as well as those of a dispersion procedure in sediments from Hirakata Bay, Tokyo Bay and the rivers which flow into Hirakata Bay are shown in Table I. As for $\mathrm{PAH}$, anthracene + phenanthrene, fluoranthene, pyrene, 1,2-benzfluorene, 1,2-benzanthracene,

Table Ia. PaH and Environmental Components in Sediment of Hrrakata Bay on a Dry Weight Basis

\begin{tabular}{|c|c|c|c|c|c|c|c|c|c|c|c|}
\hline \multirow{2}{*}{ PAH (ppm) } & \multicolumn{11}{|c|}{ Aug. 28,1973} \\
\hline & St. 1 & St. 2 & St. 3 & St. 4 & St. 5 & St. 6 & St. 7 & St. 8 & St. 9 & St. 10 & St. 11 \\
\hline Anthracene $+\mathrm{Ph}$ & 0.42 & 1.44 & 1.47 & 4.12 & 0.23 & $0 . \overline{40}$ & 0.25 & 0.20 & 0.41 & 0.34 & 0.11 \\
\hline Fluoranthene & 0.48 & 1.04 & 0.93 & 3.64 & 0.38 & 0.51 & 0.52 & 0.39 & 0.72 & 0.63 & 0.16 \\
\hline Pyrene & 0.43 & 0.91 & 0.65 & 3.52 & 0.42 & 0.73 & 0.63 & 0.39 & 0.77 & 0.51 & 0.13 \\
\hline 1,2-Benzfluorene & 0.10 & 0.16 & 0.27 & 0.70 & 0.13 & 0.28 & 0.28 & 0.17 & 0.22 & 0.17 & 0.065 \\
\hline 1,2-Benzanthracene & 0.15 & 0.32 & 0.24 & 2.09 & 0.18 & 0.26 & 0.37 & .22 & 42 & 0.33 & 0.12 \\
\hline Chrysene & 0.18 & 0.37 & 0.29 & 1.82 & 0.26 & 0.37 & 0.44 & 0.27 & 0.40 & 0.31 & 0.087 \\
\hline \multicolumn{12}{|l|}{ 3,4-Benzpyrene } \\
\hline$(+1,2$-Benzpy & 0.21 & 0.43 & 0.33 & 4.05 & 0.60 & 1.00 & 1.14 & 0.83 & 1.14 & 0.73 & 0.18 \\
\hline Perylene & 0.054 & 0.12 & 0.12 & 0.76 & 0.16 & 0.32 & 0.37 & 0.23 & 0.26 & 0.23 & 0.058 \\
\hline 3-Methylcholanthrene & $\mathrm{nd}^{*}$ & $\mathrm{nd}^{*}$ & $\mathrm{nd}^{*}$ & $\mathrm{nd}^{*}$ & $\mathrm{nd}^{*}$ & nd* & $\mathrm{nd}^{*}$ & $\mathrm{nd}^{*}$ & $\mathrm{nd}^{*}$ & $\mathrm{nd}^{*}$ & $\mathrm{nd}^{*}$ \\
\hline 1,2,5,6-Dibenzanthracene & 0.067 & 0.099 & 0.068 & 0.97 & 0.20 & 0.31 & 0.43 & 0.29 & 0.31 & 21 & $n \mathrm{~d}^{*}$ \\
\hline 1,12-Benzperylene & 0.075 & 0.53 & 0.34 & 3.47 & 0.30 & 0.97 & 1.21 & 0.87 & 1.09 & 0.67 & 0.15 \\
\hline Ignition loss $(\%)$ & 5.5 & 6.5 & 7.4 & 17.3 & 9.3 & 10.9 & 7.3 & 11.6 & 10.0 & 13.0 & 5.0 \\
\hline Conglomerate $(\%)$ & 0.9 & 8.3 & 1.3 & - & 14.8 & - & - & - & - & - & 5.1 \\
\hline Coarse sand $(\%)+$ Fine san & 89.96 & 65.9 & 82.0 & 72.0 & 70.4 & 56.6 & 77.2 & 73.5 & 67.5 & 78.4 & 92.4 \\
\hline Silt $(\%)$ & 5.5 & 19.9 & 14.1 & 24.7 & 11.7 & 38.6 & 20.6 & 21.8 & 28.7 & 18.1 & 1.1 \\
\hline
\end{tabular}




\begin{tabular}{|c|c|c|c|c|c|c|c|c|c|c|c|}
\hline Clay $(\%)$ & 3.8 & 5.9 & 2.5 & 3.3 & 3.1 & 4.7 & 2.2 & 4.7 & 3.8 & 3.5 & 1.5 \\
\hline $\mathrm{Hg}$ (ppm) & 0.16 & $\begin{array}{ll}6 & 0.19\end{array}$ & 0.24 & 40.66 & 0.24 & $\begin{array}{ll}4 & 0.41\end{array}$ & 10.52 & 20.32 & 20.38 & $\begin{array}{ll}8 & 0.41\end{array}$ & 0.26 \\
\hline $\mathrm{Zn}$ (ppm) & 191 & 318 & 454 & 728 & 317 & 789 & 547 & 325 & 416 & 395 & 124 \\
\hline $\mathrm{Pb} \quad(\mathrm{ppm})$ & 23 & 191 & 66 & 147 & 70 & 86 & 74 & 45 & 76 & 53 & 18 \\
\hline $\mathrm{Cd}$ (ppm) & 0.8 & 1.5 & 1.7 & 2.8 & 1.6 & 2.7 & 1.9 & 1.9 & 2.6 & 1.3 & 1.0 \\
\hline $\mathrm{Cu}(\mathrm{ppm})$ & 39 & 67 & 66 & 138 & 77 & 267 & 130 & 79 & 95 & 88 & 16 \\
\hline $\mathrm{Mn}(\mathrm{ppm})$ & 226 & 270 & 248 & 299 & 190 & 246 & 266 & 207 & 211 & 251 & 184 \\
\hline $\mathrm{Cr} \quad(\mathrm{ppm})$ & 29 & 31 & 44 & 37 & 57 & 441 & 180 & 113 & 63 & 69 & 24 \\
\hline
\end{tabular}

Table Ib. PAH and Environmental Components in Sedment of Hirakata Bay on a Dry Weight Basis

\begin{tabular}{|c|c|c|c|c|c|c|c|c|c|c|c|c|}
\hline \multirow{2}{*}{ PAH (ppm) } & \multicolumn{12}{|c|}{ Nov. 28,1973} \\
\hline & St. 1 & St. 2 & St. 3 & St. 4 & St. 5 & St. 6 & St. 7 & St. 8 & St. 9 & St. 13 & 3 St. 10 & St. 11 \\
\hline Anthracene + Phenanthren & e 0.087 & 70.59 & 0.39 & 1.65 & 0.40 & 0.21 & 0.19 & 1.97 & 0.93 & 30.67 & 0.24 & 0.17 \\
\hline Fluoranthene & 0.11 & 0.92 & 0.43 & 1.33 & 0.64 & 0.31 & 0.31 & 1.37 & 1.28 & 31.33 & 0.64 & 0.34 \\
\hline Pyrene & 0.11 & 0.91 & 0.38 & 1.33 & 0.63 & 0.30 & 0.30 & 1.32 & 1.19 & 1.34 & +0.60 & 0.27 \\
\hline 1,2-Benzfluorene & 0.040 & 00.27 & 0.12 & 0.23 & 0.18 & 0.089 & 90.09 & 10.42 & 0.25 & $5 \quad 0.69$ & 0.17 & 0.081 \\
\hline 1,2-Benzanthracene & 0.048 & 80.43 & 0.19 & 0.45 & 0.27 & 0.12 & 0.13 & 30.52 & 0.45 & $5 \quad 0.65$ & 0.24 & 0.14 \\
\hline Chrysene & 0.05 & 10.46 & 0.20 & 0.47 & 0.31 & 0.14 & 0.16 & $5 \quad 0.56$ & 0.55 & $5 \quad 0.86$ & 50.27 & 0.14 \\
\hline \multicolumn{13}{|l|}{ 3,4-Benzpyrene } \\
\hline$(+1,2$-Benzpyrene $)$ & 0.09 & 51.16 & 0.32 & 0.91 & 0.52 & 0.22 & 0.24 & 0.83 & 0.81 & 11.64 & +0.38 & 0.21 \\
\hline Perylene & 0.075 & 50.44 & 0.095 & 90.24 & 0.14 & 0.07 & 20.07 & 760.22 & 0.19 & 70.45 & 0.12 & 0.078 \\
\hline 3-Methylcholanthrene & $n d^{*}$ & $\mathrm{nd}^{*}$ & $n d^{*}$ & $\mathrm{nd}^{*}$ & $\mathrm{nd}^{*}$ & $n d^{*}$ & $n d^{*}$ & $n d^{*}$ & $\mathrm{nd}^{*}$ & $\mathrm{nd}^{*}$ & $\mathrm{nd}^{*}$ & nd* \\
\hline 1,2,5,6-Dibenzanthracene & $n d^{*}$ & $n d^{*}$ & 0.10 & $n d^{*}$ & 0.11 & 0.04 & 70.05 & 560.18 & 0.15 & 50.54 & +0.077 & 0.048 \\
\hline 1,12-Benzperylene & 0.09 & 901.15 & 0.38 & 0.78 & 0.64 & 0.12 & 0.32 & $2 \quad 0.91$ & 1.09 & $9 \quad 1.74$ & 0.43 & 0.11 \\
\hline Ignition loss $(\%)$ & 5.4 & 10.1 & 8.3 & 4.4 & 12.4 & 9.7 & 12.5 & 12.3 & 9.8 & 17.0 & 8.2 & - \\
\hline Conglomerate $(\%)$ & 1.7 & 一 & - & 1.4 & - & - & - & - & - & - & - & - \\
\hline \multicolumn{13}{|l|}{ Coarse sand $(\%)$} \\
\hline+ Fine sand $(\%)$ & 84.0 & 64.2 & 77.3 & 96.5 & 49.0 & 44.9 & 52.2 & 60.4 & 64.6 & 74.6 & 87.1 & - \\
\hline Silt $(\%)$ & 11.8 & 32.0 & 22.2 & 1.1 & 46.6 & 51.0 & 43.8 & 34.7 & 33.1 & 20.5 & 10.7 & - \\
\hline Clay $(\%)$ & 2.5 & 3.8 & 0.5 & 1.1 & 4.3 & 4.1 & 3.9 & 4.9 & 2.2 & 4.9 & 2.1 & - \\
\hline $\mathrm{Hg}(\mathrm{ppm})$ & 0.08 & $8 \quad 1.06$ & $\begin{array}{ll}6 & 0.14\end{array}$ & $4 \quad 0.10$ & 0.49 & 0.32 & 0.29 & $\begin{array}{ll}9 & 0.31\end{array}$ & 0.37 & $\begin{array}{ll}7 & 1.17\end{array}$ & $7 \quad 0.22$ & 一 \\
\hline $\mathrm{Zn}(\mathrm{ppm})$ & 190 & 507 & 503 & 167 & 698 & 654 & 341 & 474 & $466 \quad 1$ & 1762 & 369 & - \\
\hline $\mathrm{Pb} \quad(\mathrm{ppm})$ & 42 & 191 & 75 & 45 & 132 & 93 & 52 & 89 & 108 & 861 & 44 & - \\
\hline $\mathrm{Cd}(\mathrm{ppm})$ & 1.7 & 2.6 & 1.7 & 1.4 & 2.8 & 2.5 & 2.2 & 2.3 & 2.2 & 6.8 & 1.4 & - \\
\hline $\mathrm{Cu}$ (ppm) & 42 & 162 & 75 & 45 & 151 & 136 & 90 & 114 & 115 & 462 & 55 & - \\
\hline $\mathrm{Mn}(\mathrm{ppm})$ & 345 & 385 & 321 & 250 & 342 & 410 & 325 & 308 & 312 & 305 & 277 & - \\
\hline $\mathrm{Cr}$ (ppm) & 48 & 45 & 77 & 18 & 101 & 164 & 94 & 100 & 56 & 455 & 53 & - \\
\hline
\end{tabular}

Table Ic. PAH and Environmental Components in Sedment of Hirakata Bay on a Dry Weight Basis

\begin{tabular}{lccccccccccc}
\multicolumn{1}{c}{ PAH $(\mathrm{ppm})$} & \multicolumn{10}{c}{ Feb. 15, 1974 } \\
\cline { 2 - 10 } & St. 1 & St. 2 & St. 3 & St. 4 & St. 5 & St. 6 & St. 7 & St. 8 & St. 9 & St. 10 & St. 11 \\
\hline Anthracene+Phenanthrene & 0.94 & 1.90 & 0.37 & 1.46 & 0.85 & 0.92 & 0.35 & 20.0 & 1.34 & 1.13 & 0.045 \\
Fluoranthene & 0.64 & 2.49 & 0.40 & 1.34 & 1.38 & 1.04 & 0.57 & 10.1 & 2.40 & 1.31 & 0.090 \\
Pyrene & 0.56 & 2.30 & 0.36 & 1.36 & 1.45 & 0.90 & 0.58 & 10.8 & 2.43 & 1.34 & 0.10 \\
1,2-Benzfiuorene & 0.19 & 0.48 & 0.10 & 0.19 & 0.27 & 0.26 & 0.18 & 3.59 & 0.46 & 0.27 & 0.032 \\
1,2-Benzanthracene & 0.30 & 0.91 & 0.16 & 0.46 & 0.53 & 0.35 & 0.26 & 4.78 & 1.02 & 0.48 & 0.056 \\
Chrysene & 0.35 & 1.12 & 0.20 & 0.56 & 0.71 & 0.49 & 0.31 & 4.69 & 1.15 & 0.59 & 0.060 \\
3,4-Benzpyrene & & & & & & & & & &
\end{tabular}




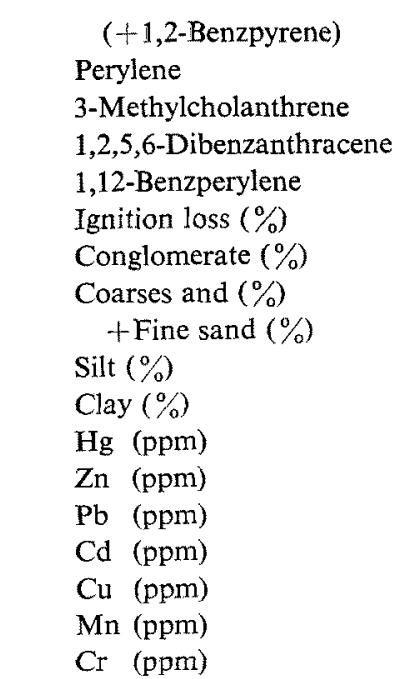

\begin{tabular}{|c|c|c|c|c|c|c|c|c|c|c|}
\hline .40 & 62 & 0.26 & 0.80 & 1.00 & 0.52 & 0.44 & 6.07 & 1.64 & 0.77 & 0.090 \\
\hline 0.10 & 0.41 & 0.078 & 0.15 & 0.20 & 0.13 & 0.14 & 1.32 & 0.29 & 0.16 & 0.035 \\
\hline$n d^{*}$ & $n d^{*}$ & nd* & $\mathrm{nd}^{*}$ & $\mathrm{nd}^{*}$ & $\mathrm{nd}^{*}$ & $\mathrm{nd}^{*}$ & $\mathrm{nd}^{*}$ & $\mathrm{nd}^{*}$ & $\mathrm{nd}^{*}$ & nd* \\
\hline 0.13 & 0.44 & 0.081 & 0.17 & 0.21 & 0.13 & 0.13 & 1.30 & 0.30 & 0.14 & 0.024 \\
\hline 0.51 & 2.06 & 0.34 & 0.78 & 1.09 & 0.55 & 0.54 & 4.37 & 1.56 & 0.69 & 0.11 \\
\hline .4 & 6.9 & 6.5 & 7.2 & 12.0 & 11.3 & 10.2 & 9.4 & 13.1 & 9.1 & 5.1 \\
\hline - & 一 & - & - & - & 一 & - & - & - & - & - \\
\hline 5.8 & 75.4 & 83.7 & 92.4 & 37.2 & 46.6 & 45.1 & 54.8 & 41.9 & 82.8 & 92.1 \\
\hline 4.8 & 23.0 & 15.2 & 5.4 & 57.9 & 46.9 & 48.6 & 41.3 & 53.2 & 15.1 & 4.9 \\
\hline 9.4 & 1.6 & 1.1 & 2.2 & 5.0 & 6.5 & 6.3 & 3.9 & 4.9 & 2.1 & 2.9 \\
\hline 0.92 & 0.68 & 0.20 & 0.25 & 0.67 & 0.45 & 0.41 & 0.44 & 0.86 & 0.30 & 0.19 \\
\hline & 687 & 421 & 191 & 590 & 744 & 380 & 512 & 683 & 270 & 148 \\
\hline ת & 241 & 56 & 38 & 118 & 103 & 52 & 83 & 158 & 40 & 19 \\
\hline 2.9 & 2.9 & 1.1 & 1.2 & 2.3 & 1.8 & 1.7 & 2.3 & 2.8 & 1.1 & 0.7 \\
\hline & 116 & 61 & 44 & 136 & 136 & 92 & 112 & 147 & 53 & 22 \\
\hline & 344 & 289 & 225 & 284 & 373 & 276 & 263 & 301 & 304 & 336 \\
\hline & 39 & 70 & 20 & 91 & 178 & 124 & 110 & 65 & 47 & 35 \\
\hline
\end{tabular}

$\mathrm{nd}^{*}<0.020 \mathrm{ppm}$

Table Id. PAH and Environmental. Components in Sediment of Hirakata Bay on a Dry Weight Basis

\begin{tabular}{|c|c|c|c|c|c|c|c|c|c|c|c|c|}
\hline \multirow{2}{*}{ PAH (ppm) } & \multicolumn{12}{|c|}{ May 28,1974} \\
\hline & St. 1 & St. 2 & St. 3 & St. 4 & St, 5 & St. 6 & St. 7 & St. 8 & St. 9 & St. 13 & 3 St. 10 & St. 11 \\
\hline Anthracene + Phenanthren & 0.82 & 0.46 & 2.57 & 0.21 & 0.34 & 0.11 & 0.11 & 1.06 & 0.82 & 20.99 & 0.075 & 50.004 \\
\hline Fluoranthene & 0.86 & 0.73 & 2.06 & $5 \quad 0.62$ & 0.74 & 0.18 & 0.34 & 1.48 & 0.86 & $\begin{array}{ll}6 & 1.86\end{array}$ & 0.18 & 0.007 \\
\hline Pyrene & 0.78 & 0.69 & 1.73 & 0.71 & 0.74 & 0.16 & 0.33 & 1.42 & 0.86 & $\begin{array}{ll}6 & 1.87\end{array}$ & 0.16 & 0.007 \\
\hline 1,2-Benzfluorene & 0.19 & 0.17 & 0.37 & 0.14 & 0.16 & 0.036 & 60.072 & 20.54 & 0.28 & $8 \quad 0.49$ & 0.052 & 20.002 \\
\hline 1,2-Benzanthracene & 0.39 & 0.29 & 0.65 & 0.31 & 0.56 & 0.11 & 0.18 & 1.02 & 0.62 & 20.76 & 0.11 & 0.005 \\
\hline Chrysene & 0.45 & 0.42 & 1.03 & 0.42 & 0.66 & 0.12 & 0.22 & 0.96 & 0.87 & 71.06 & 0.12 & 0.005 \\
\hline \multicolumn{13}{|c|}{  } \\
\hline$(+1,2$-Benzpy & 0.70 & 0.61 & 1.43 & 0.64 & 1.12 & 0.36 & 0.60 & 1.94 & 1.46 & $6 \quad 2.06$ & 0.12 & 0.008 \\
\hline Perylene & 0.14 & $n d^{*}$ & 0.21 & 0.091 & 10.20 & $\mathrm{nd}^{*}$ & $\mathrm{nd}^{*}$ & 0.33 & 0.20 & $0 \quad 0.44$ & $\mathrm{nd}^{*}$ & 0.002 \\
\hline 3-Methylcholanthrene & $n d^{*}$ & $n d^{*}$ & nd* & $\mathrm{nd}^{*}$ & $\mathrm{nd}^{*}$ & $\mathrm{nd}^{*}$ & $n d^{*}$ & $\mathrm{nd}^{*}$ & $\mathrm{nd}^{*}$ & $\mathrm{nd}^{*}$ & $\mathrm{nd}^{*}$ & $\mathrm{nd} \mathrm{d}^{* *}$ \\
\hline 1,2,5,6-Dibenzanthracer & 0.21 & 0.16 & 0.32 & 20.13 & 0.40 & 0.13 & 0.18 & 0.50 & 0.29 & $\begin{array}{ll}9 & 0.49\end{array}$ & 0.034 & 340.005 \\
\hline 1,12-Benzperylene & 0.41 & 0.38 & 0.69 & 0.28 & 1.54 & 0.46 & 0.63 & 1.36 & $5 \quad 1.33$ & 31.23 & 0.11 & 10.010 \\
\hline Ignition loss $\left({ }^{\circ}\right.$ & 7.7 & 7.3 & 13.7 & 4.8 & 12.4 & 7.3 & 12.1 & 11.1 & 11.3 & 14.8 & 3.8 & 2.6 \\
\hline Conglomerate $(\%)$ & - & - & - & 0.6 & - & - & - & - & - & - & 2.0 & - \\
\hline \multicolumn{13}{|l|}{ Coarse sand $(\%)$} \\
\hline+ Fine sand $(\%)$ & 87.6 & 61.2 & 81.6 & 94.4 & 47.9 & 67.5 & 47.7 & 48.7 & 53.8 & 57.4 & 91.3 & 98.6 \\
\hline Silt $(\%)$ & 9.6 & 33.2 & 17.0 & 5.0 & 46.0 & 30.2 & 45.0 & 47.6 & 42.9 & 40.3 & 6.7 & 0.9 \\
\hline Clay $(\%)$ & 2.7 & 5.5 & 1.4 & - & 6.2 & 2.4 & 7.3 & 3.7 & 3.3 & 2.3 & - & 0.5 \\
\hline $\mathrm{Hg}(\mathrm{ppm})$ & 0.18 & 1.02 & 0.28 & 0.20 & 0.65 & 0.36 & 0.77 & 0.44 & 0.49 & $9 \quad 1.13$ & 0.17 & $\begin{array}{ll}7 & 0.12\end{array}$ \\
\hline $\mathrm{Zn}(\mathrm{ppm})$ & 261 & 590 & 525 & 185 & 518 & 4706 & 6115 & 5015 & 5421 & 12821 & 128 & 102 \\
\hline $\mathrm{Pb} \quad(\mathrm{ppm})$ & 42 & 129 & 79 & 83 & 106 & 64 & 87 & 80 & 127 & 620 & 20 & 17 \\
\hline $\mathrm{Cd}(\mathrm{ppm})$ & 0.8 & 1.8 & 1.6 & 1.1 & 2.8 & 1.7 & 2.4 & 1.8 & 2.2 & 5.9 & 0.5 & 0.7 \\
\hline $\mathrm{Cu}(\mathrm{ppm})$ & 50 & 117 & 70 & 56 & 128 & 107 & 147 & 100 & 116 & 315 & 20 & 12 \\
\hline$M n(p p m)$ & 292 & 307 & 243 & 254 & 276 & 260 & 317 & 307 & 262 & 263 & 260 & 428 \\
\hline $\mathrm{Cr} \quad(\mathrm{ppm})$ & 42 & 42 & 61 & 28 & 71 & 146 & 183 & 98 & 47 & 284 & 31 & 31 \\
\hline
\end{tabular}

$\mathrm{nd}^{*}<0.020 \mathrm{ppm} \quad \mathrm{nd}^{* *}<0.002 \mathrm{ppm}$ 
chrysene, 3,4-benzpyrene (1,2-benzpyrene), 1,2,5,6-dibenzanthracene and 1,12-benzperylene were identified and determined. Concentrations of $\mathrm{PAH}$ in sediments from the rivers and Hirakata Bay were within the range of several hundred $\mu \mathrm{g} / \mathrm{kg}$ to several $\mathrm{mg} / \mathrm{kg}$ of dry samples, about an order higher than those in sediment from Tokyo Bay adjacent to Hirakata Bay, and those of several to several hundred $\mu \mathrm{g} / \mathrm{kg}$ of dry samples in sediments from Buzzards Bay, USA (Giger et al. ${ }^{1 \prime}$ ).

The ratios of the sum of (anthracene- + phenanthrene + fluoranthene + pyrene) concentrations to total amount of individual PAH concentration at a same sampling station, were amounted to $70 \sim 80 \%$ for the river and bay waters, while those for the river sediments and the bay sediments were as low as $50 \sim 60 \%$ and $30 \sim 50 \%$, respectively. These data coincides well with those obtained for the samples from Tokyo Bay (Matsushima, in preparation). Namely, the ratios were amounted to more than $60 \%$ for the Tama River water which flows into Tokyo Bay, while those for estuary sediments and sediments of Tokyo Bay were as low as about $50 \%$ and $30 \sim 40 \%$, respectively. The difference in the ratios between water and sediment may be due to the different rates of decomposition, volatilization and/or precipitation of PAH from water to sediment. Experiments on the mode of disappearance of PAH in Hirakata Bay sediments, which indicated that the smaller the molecular weight of $\mathrm{PAH}$ was, the greater was its rate of disappearance (Matsushima, in preparation). Further, studies on core samples of Tokyo Bay sediments showed that the concentrations of PAH tend to be maximum at the surface layer of the sediment and decrease toward lower direction, and the smaller the molecular weight of PAH is, the greater is its rate of decrease (Matsushima, in preparation). Based on these facts, it is presumed that the difference in the ratios between water and sediment is mainly due to the different decomposition rate of PAH.

Applying statistical techniques, correlations between PAH and environmental components were examined. The author assumed that the correlation with the level of risk below $5 \%$ is statistically significant. The sample collected from St. 8 on Feb. 15, 1974, was excluded from the statistical analysis according to the rejection test, because the PAH concentrations in this station are remarkably high compared with those in sediments sampled at other stations, probably due to direct dumping from fishing boats. Results of the correlations of PAH and heavy metals in sediments are shown in Table II. Significant positive correlations were statistically found between total amount of $\mathrm{PAH}$ and $\mathrm{Pb}, \mathrm{Hg}$ in sediments of Hirakata Bay, between total amount of PAH and $\mathrm{Cd}$, and between total amount of $\mathrm{PAH}$ and $\mathrm{Cu}, \mathrm{Zn}$, with the level of risk below 1,2 and $5 \%$ respectively. Similar correlations were also found between individual PAH, namely 3, 4-benzpyrene (1, 2benzpyrene), 1, 12-benzperylene, pyrene, chrysene, and heavy metals such as $\mathrm{Pb}, \mathrm{Hg}$, $\mathrm{Cd}, \mathrm{Cu}, \mathrm{Zn}$. On the contrary, in river sediments, such correlations were only partly ob-

Table II. Correlation Coefficients between PAH and Metal Concentrations in Sediment

\begin{tabular}{|c|c|c|c|c|c|c|}
\hline & \multicolumn{2}{|c|}{ Total PAH } & \multicolumn{2}{|c|}{ 3,4-Benzpyrene (1,2-Benzpyrene) } & \multicolumn{2}{|c|}{ 1,12-Benzperylene } \\
\hline & River & Bay & River & Bay & River & Bay \\
\hline $\mathrm{Pb}$ & 0.46 & $0.59^{a}$ & 0.42 & $0.56^{a}$ & $0.57^{c}$ & $0.49^{\circ}$ \\
\hline $\mathrm{Hg}$ & 0.30 & $0.61^{a}$ & 0.34 & $0.64^{a}$ & 0.41 & $0.65^{a}$ \\
\hline $\mathrm{Cd}$ & 0.49 & $0.51^{b}$ & $0.53^{\circ}$ & $0.50^{\circ}$ & $0.66^{a}$ & $0.50^{c}$ \\
\hline $\mathrm{Cu}$ & 0.37 & $0.44^{c}$ & 0.32 & $0.48^{\circ}$ & 0.48 & $0.47^{\circ}$ \\
\hline $\mathrm{Zn}$ & 0.35 & $0.50^{\circ}$ & 0.33 & $0.51^{b}$ & 0.40 & $0.48^{\circ}$ \\
\hline $\mathrm{Mn}$ & 0.04 & -0.04 & 0.11 & -0.33 & 0.23 & -0.18 \\
\hline $\mathrm{Cr}$ & -0.13 & 0.13 & -0.15 & 0.23 & -0.10 & 0.19 \\
\hline
\end{tabular}

a $p<0.01$

${ }^{b} p<0.02$

$c p<0.05$


served. In sediments from Osaka Bay, significant positive correlations were statistically found between 3,4-benzpyrene and $\mathrm{Cd}, \mathrm{Cu}$, $\mathrm{Pb}$ (Kawakami et al. ${ }^{6}$ ). While, correlations between 3,4-benzpyrene and heavy metals in dust in the atmosphere have been studied by Tomita $^{9)}$ and Matsushita et al. ${ }^{10)}$ According to Tomita, significant positive correlations were statistically observed between 3,4-benzpyrene and $\mathrm{Cd}, \mathrm{Fe}, \mathrm{Pb}, \mathrm{Cr}, \mathrm{Ni}$ in dust from air of Osaka City. Matsushita et al. have reported that in dust from air of Kawasaki City, Kanagawa Pref., heavy metals which correlated significantly with 3, 4-benzpyrene, were $\mathrm{Pb}, \mathrm{Cd}$ and $\mathrm{V}$. Therefore, by use of correlations of PAH and other environmental pollutants such as heavy metals, the dynamics of $\mathrm{PAH}$ in air-water interface is explained.

The correlations between PAH, ignition loss and clay, silt contents were investigated. The correlation between total amount of PAH and ignition loss is shown in Fig. 2. For bay sedi-

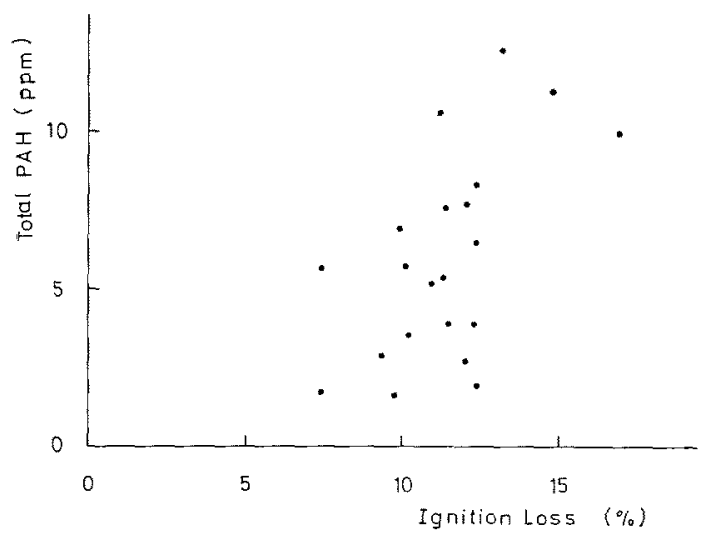

Frg. 2. Correlation between Total Amount of PAH and Ignition Loss in Sediment of Hirakata Bay. $r=0.55, p<0.02$.

ments, a significant positive correlation was statistically found with the level of risk below $2 \%$, while in the river sediments no such correlation could be observed. For bay sediments, similar correlations were found between 3, 4-benzpyrene (1,2-benzpyrene), 1, 12-benzperylene and ignition loss with correlation coefficients of 0.50 and 0.45 , respectively, with the level of risk below $5 \%$. These facts that positive corerlations can not be found for river sediments may be explained by that, in river sediments, so many kinds of organic substances come from a variety of sources and their decomposition rates are remarkably different from each other. On the other hand, in bay sediments, the most part of unstable compounds are easily decomposed and the residue may be in relatively stable states. However, between total amount of PAH and clay content, the sum of (clay+silt) contents, no clear correlations could be found for both river and bay sediments.

The correlation between ignition loss and the sum of (clay+silt) contents is shown in Fig. 3. For both river and bay sediments

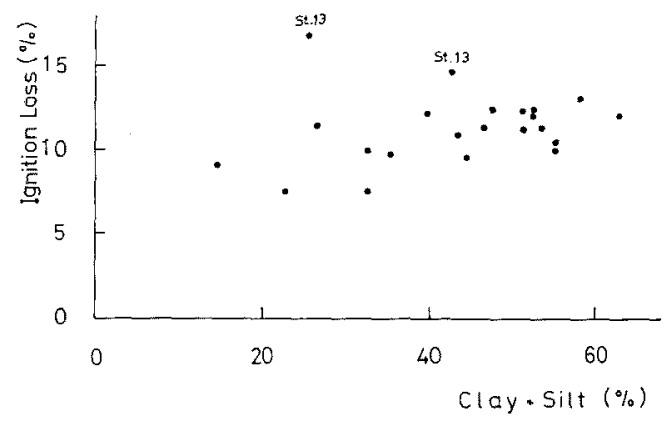

Frg. 3. Correlation between Ignition Loss and the Sum of (Clay + Silt) Contents in Sediment of Hirakata Bay. $r=0.37 ; r=0.67, p<0.01$ (except St. 13).

(except St. 13) a significant positive correlation with the level of risk below $1 \%$ was statistically found between the above two factors. Also, between ignition loss and clay content, the author found statistically a significant positive correlation with the correlation coefficient of 0.68 and the level of risk below $1 \%$ for river sediments, while a correlation coefficient was 0.77 and the level of risk below $0.1 \%$ for bay sediments (except St. 13). Based on these facts, it is presumed that organic substances in sediments are present in an adsorbed form to clay and silt.

Acknowledgments. The author wishes to thank Professor T. Hanya for giving the useful comments, and Assistant Professor R. Nakagawa for analyzing of heavy metals in sediments. 


\section{REFERENCES}

1) W. Giger and M. Blumer, Anal. Chem., 46, 1663 (1974).

2) J. Greffard and J. Meury, Cah. Oceanogr., 19, 457 (1967).

3) L. Mallet, A. Perdriau and J. Perdriau, $C . R$. Acad. Sci., 256, 3487 (1963).

4) I. Tomita, S. Saitou, S. Nakamura and K. Murayama, Jpn. Hyg. Chem., 23, 200 (1977).

5) R. Tatsukawa, M. Kawano and T. Wakimoto,
Bunseki-Kagaku, 26, 412 (1977).

6) Y. Kawakami and H. Nishimura, J. Oceanogr. Soc. Jpn., 32, 175 (1976).

7) H. Matsushima and T. Hanya, Agric. Biol. Chem., 43, (in press).

8) R. Nakagawa and Y. Ohyagi, Nippon Kagaku Kaishi, 23, 2331 (1974).

9) K. Tomita, J. Jpn. Soc. Air Pollut., 10, 742 (1976).

10) H. Matsushita, H. Shimada, T. Ishida, M. Nagata and M. Ichihashi, J. Jpn. Soc. Air Pollut., 10, 580 (1975). 